\title{
Accounting
}

homepage: www.GrowingScience.com/ac/ac.html

\section{Financial development and poverty reduction in developing countries}

\section{Zulhera and Cicih Ratnasih $^{\mathbf{b}^{*}}$}

${ }^{a}$ STIE Bangkinang, Kampar, Indonesia

${ }^{b}$ University of Borobudur Jakarta, Indonesia

\section{H R O N I C L E}

\begin{tabular}{l}
\hline Article history: \\
Received: October 29, 2020 \\
Received in revised format: \\
November 272020 \\
Accepted: December 15, 2020 \\
Available online: \\
December 15,2020 \\
\hline Keywords: \\
Investment $t-1$ \\
Investment $t-2$ \\
Provincial Minimum Wages \\
Job Opportunities \\
Poverty
\end{tabular}

\section{Introduction}

The economic development is a processto a better direction improvement of the community welfare which is marked by the increasing of people income per capita of the population for long term (Achsani et al., 2010). The factors which could encourage economic growth include the availability of human resources, natural resources, capital formation, and technology. The problem faced by many countries concerning people's welfare is the inability of society to meet their daily needs. This is due to the high poverty rate that limits their ability to fulfill their daily needs (Jalilian \& Kirkpatrick, 2002). Poverty had captured the attention of all circles, so that the problem of poverty had become one of the important issues in Millennium Development Goals or MDGs (Bouoiyour \& Miftah, 2014). The Central Bureau of Statistics (2002, p. 491) defined poverty as the inability to meet the minimum standard of basic needs covering both food and non-food needs. According to BPS, a poor person is someone who has an average per capita expenditure per month below the poverty line, where the poverty line limit for each province of various size. In Indonesia, the problem of poverty is still large and increasingly complex, which is a challenge for current development. 
The poverty becomes a serious problem because of the impact it causes, such as millions of people are unable to meet their foods, clothes, and shelters, millions of children cannot get their right to have quality education, difficulties in financing health services, lack of savings, and non-existence investment and so on (Collier \& Dollar, 2002). Based on the causes, poverty can be divided into two types. First, cultural poverty is the poverty caused by the cultural elements in a particular area. Second, structural poverty is the poverty caused by inadequate condition of society against an unfair social system or order, therefore they are in a weak condition to access and develop themselves from the grip of poverty.

According to Kaplale (2012, p.87), the factors that influence poverty include the decreasing of productivity, the limitation of employment opportunities, the low of education levels of family heads, and the limitation of capital access (cash). Meanwhile, according to Hartomo and Aziz (1997, p.57), the things that affect poverty are economic growth, low education, the limitation of natural resources, the limitation of employment opportunities, the limitation of capital, and family burdens. All of these factors constitute a vicious circle in the problem of poverty.

The development process requires high income and fast economic growth. In many countries economic growth can have the effects on reducing poverty levels. The economic growth is not too influential in alleviating poverty, but economic growth accompanied by equal distribution of income can reduce poverty levels (Wongdesmiwati, 2009, p. 78). Gross Regional Domestic Product is an indicator used to measure the economic performance, so the higher of the Gross Regional Domestic Product, the higher of declining of poverty and vice versa. Basically, the development is always focus on improving social welfare, the indicators are not only can be seen from success in the economic field, but also in the social field. In the economic sector, the measurements are from the increasing of economic growth or the increasing of per capita income in long term, the poverty reduction, unemployment, income inequality (income gap), expanding employment opportunities, and the stability of the inflation rate. A stable economic development should be marked by regional economic growth and the achievement of other goals. In reality, the development goals reach in parallel. Development programs and activities that focus on the increasing of high economic growth are usually followed by the increasing of income inequality among individuals, groups, and regions, but do not directly reduce the poverty and the unemployment significantly. Riau is a province which has many productive sectors, such as agriculture, plantation, trade, fisheries, and others. However, the development in Riau is still improving in every district or city, there are still many income inequalities that need to be corrected that causes poverty is still a problem in this area. The Central Statistics Agency recorded the total population and number of poor people in Riau Province for the 2010-2018 period as shown in Table 1.

Table 1

Number of poor people in Riau Province for the 2010-2018

\begin{tabular}{|c|c|c|c|c|c|}
\hline \multirow{2}{*}{ Years } & \multicolumn{2}{|c|}{ People } & \multicolumn{2}{|c|}{ Poor People } & \multirow{2}{*}{ \% Poor People } \\
\hline & Amount & Growth & Amount & Growth & \\
\hline 2010 & 2.866 .934 & & 558.000 & & 19,46 \\
\hline 2011 & 2.943 .836 & 2,68 & 472.500 & $-15,32$ & 16,05 \\
\hline 2012 & 3.021 .494 & 2,64 & 476.500 & 0,85 & 15,77 \\
\hline 2013 & 3.099 .760 & 2,59 & 511.500 & 7,35 & 16,50 \\
\hline 2014 & 3.178 .486 & 2,54 & 498.000 & $-2,64$ & 15,67 \\
\hline 2015 & 3.257 .561 & 2,49 & 562.920 & 13,04 & 17,28 \\
\hline 2016 & 3.336 .874 & 2,43 & 501.590 & $-10,89$ & 15,03 \\
\hline 2017 & 3.416 .307 & 2,38 & 496.390 & $-1,04$ & 14,53 \\
\hline 2018 & 3.495 .705 & 2,32 & 494.260 & $-0,43$ & 14,14 \\
\hline Average & 3.179 .662 & 2,51 & 507.962 & $-1,14$ & 16,05 \\
\hline
\end{tabular}

Source: Central Statistics Agency of Riau Province

In Table 1. it can be seen that the population of Riau Province during the 2010-2018 period increased with the average growth of $2.51 \%$. The increase in population in Riau Province is due to the increasing in job seekers in Riau Province, because Riau is one of the promising areas for residents of neighboring areas such as West Sumatra, South Sumatra, and North Sumatra.

In the same period, it can be seen that the number of poor people in Riau Province during the 2010-2017 period decreased with the annual average decline of $1.14 \%$. This can also be seen from the comparison between the number of people and the number of poor people in Riau Province in the same period. From the data in Table1, the average ratio of the poor during the 2010-2018 period was $16.05 \%$. This means that $16.05 \%$ of the total population of Riau Province is still categorized as poor.

The poverty line is the ability to meet basic needs (basic needs approach). The poverty line in Riau Province during the 20102017 period can be seen in Table 2. 
Table 2

The poverty line in Riau Province during the 2010-2017

\begin{tabular}{|c|c|c|c|c|c|c|c|c|}
\hline City & \multicolumn{8}{|c|}{ Poverty Line (capita/Mount) } \\
\hline Indragiri Hulu & 292.610 & 325.185 & 345.423 & 369.210 & 387.172 & 396.088 & 419.737 & 432.598 \\
\hline Pelalawan & 359.431 & 374.611 & 398.742 & 429.452 & 438.949 & 451.528 & 473.240 & 487.648 \\
\hline Siak & 269.244 & 299.609 & 316.774 & 336.671 & 351.610 & 363.879 & 391.039 & 414.501 \\
\hline Kampar & 279.606 & 308.446 & 320.907 & 336.681 & 348.373 & 360.324 & 375.716 & 398.138 \\
\hline Rokan Hilir & 250.267 & 270.412 & 282.767 & 296.770 & 308.248 & 317.220 & 345.953 & 367.338 \\
\hline Kepulauan Meranti & 339.327 & 358.617 & 371.169 & 386.745 & 397.937 & 403.535 & 427.938 & 445.025 \\
\hline Pekanbaru & 326.670 & 339.965 & 357.200 & 381.287 & 399.451 & 416.479 & 435.082 & 473.788 \\
\hline Dumai & 287.975 & 298.127 & 311.891 & 328.158 & 341.525 & 353.079 & 369.624 & 403.244 \\
\hline RIAU & 301.190 & 296.379 & 310.603 & 350.129 & 379.223 & 399.211 & 426.001 & 456.493 \\
\hline
\end{tabular}

Source: Riau Central Bureau of Statistics

The poverty line for Riau Province in 2017 was Rp. 466,493 per capita per month, increased from 6.67 percent in 2016 amounted to Rp. 426,001 per capita per month. When compared to the poverty line of Riau Province with the National Poverty Line, it is known that the poverty line of Riau Province is higher than the national one, because the national poverty line is only Rp. 401,000, - per capita. And when compared to the world bank poverty standard where the line standardpoverty of The World Bank is in the range of USD 1.9 or around Rp. 27,000 in the current exchange rate $(\$ 1=\mathrm{Rp} .14,515)$ is Rp. 810,000 a month. This means that the poverty line in Riau Province is still low compared to World Bank standards. The causes of poverty are in the vicious cycle of poverty theory, Nurkse 1953 in Kuncoro (1997: 132), the left behind and underdevelopment of Human Resources (HR) (as reflected by the low Human Development Index / HDI), market imperfections, and lack of capital causes low labor productivity (resulting in high unemployment). Low labor productivity results in low income (reflected by low wages) which will have implications for low savings and investment. Low investment results in low capital accumulation so that the job creation process is low (Kuncoro, 1997, p. 137). Another factor that is thought to affect poverty is job opportunities. The job opportunities referred to the number of workforce that can be absorbed by the available job fields in Riau Province. From Figure 3. Below showed the development of the workforce during 2010-2017increased every year with the annual average growth of $4.10 \%$. The same thing was also followed by the increasing in job opportunities in Riau Province with the average annual growth of 3.79\%. However, the data still describes a problem, namely that not all of the workforce has been absorbed by the available employment opportunities in Riau Province.

Table 3

Comparison between Labor Force and Employment Opportunities in Riau Province in 2010-2017

\begin{tabular}{ccccc}
\hline Years & \multicolumn{2}{c}{ Workforce } & & \multicolumn{2}{c}{ Job Opportunities } \\
\cline { 2 - 5 } & Amount & Growth & 2.170 .247 & Growth \\
\hline 2010 & 2.260 .862 & 5,16 & 2.311 .171 & 6,49 \\
2011 & 2.377 .494 & 3,52 & 2.399 .851 & 3,84 \\
2012 & 2.461 .112 & 1,97 & 2.479 .493 & 3,32 \\
2013 & 2.509 .501 & 7,40 & 2.518 .485 & 1,57 \\
2014 & 2.695 .247 & 2,82 & 2.554 .296 & 1,42 \\
2015 & 2.771 .349 & 7,82 & 2.765 .946 & 8,29 \\
2016 & 2.987 .952 & 0,05 & 2.781 .021 & 0,55 \\
2017 & 2.989 .585 & 4,03 & 2.915 .597 & 4,84 \\
2018 & 3.110 .000 & $\mathbf{4 , 1 0}$ & $\mathbf{2 . 5 4 4 . 0 1 2}$ & $\mathbf{3 , 7 9}$ \\
\hline Average & $\mathbf{2 . 6 8 4 . 7 8 9}$ & &
\end{tabular}

Source: Central Statistics Agency of Riau Province

In Table 3, in line with the increasing of the number of the workforce, the Labor Force Participation Rate in Riau Province also increases. The increase in the Labor Force Participation Rate indicates the increasing of economic potential from the supply side of labor. Based on Central Statistics Agency data, it is known that during the past year, the employment category has experienced in the increasing of the percentage or number of workers, especially in the processing industry, the provision of accommodation, and food and beverage, as well as financial and insurance services. Meanwhile, the decline of employment experienced in the percentage of the working population, especially in trade and government administration. The opening of job opportunities in a region directly will affect absorbing local labor, where the wages and income received affecting on increasing the standard of living of the community and the sustainably (Frank \& Bernanke, 2007). It can increase the economic growth of the area. Unequal 
employment opportunities will also lead to social inequality and the increasing of the poverty. The absorption of labor in Riau Province until August 2018 was still dominated by the working population with elementary school graduated and below as many as 1.01 million people (34.64 percent), junior high school graduated as much as 0.54 million people (18.57 percent), high school graduated as many as 0.70 million people (24.06 percent), and vocational high school graduated as many as 0.29 million people (10.15 percent), mean that their productivity is still low. Another, more in-depth indicator regarding the workforce is full-time and part-time workers, which explains that not all workers have high productivity. The percentage of part-time workers in August 2018 was 35.76 percent, consisting of part-time workers of 27.08 percent and underemployed workers by 8.68 percent. The Increasing of investment can stimulate the business world and create job opportunities which stimulate economic development in a region. The investment can develop due to several factors such as global, regional, and local aspects. Riau is one of the potential areas for investors to invest their capital in Riau's natural resources. This can trigger local governments to create a conducive investment atmosphere by improving policies and regulations that benefit investors and the government. The following shows the development of investment in Riau Province in 2010-2018.

Table 4

Development of Investment in Riau Province 2010-2018 (In Billion Rupiah)

\begin{tabular}{|c|c|c|c|}
\hline \multirow{2}{*}{ Years } & \multicolumn{2}{|c|}{ Investment } & \multirow[b]{2}{*}{ Amount } \\
\hline & FDI & Domestic Inv & \\
\hline 2010 & 86.634 .000 & 1.037 .131 & 87.671 .131 \\
\hline 2011 & 212.336 .000 & 7.462 .597 & 219.798 .597 \\
\hline 2012 & 115.285 .600 & 5.450 .432 & 120.736 .032 \\
\hline 2013 & 130.494 .614 & 4.874 .269 & 135.368 .883 \\
\hline 2014 & 136.457 .450 & 7.707 .564 & 144.165 .014 \\
\hline 2015 & 65.339 .000 & 9.943 .044 & 75.282 .044 \\
\hline 2016 & 86.105 .300 & 6.613 .745 & 92.719 .045 \\
\hline 2017 & 10.611 .000 & 10.829 .836 & 21.440 .836 \\
\hline 2018 & 10.329 .000 & 9.055 .398 & 19.384 .398 \\
\hline Average & 94.843 .552 & 6.997 .113 & 101.840 .664 \\
\hline
\end{tabular}

Source: Central Statistics Agency of Riau Province

From Table 4, it can be seen that the development of investment in Riau Province during 2010-2018 greatly fluctuated. The annual average realization of foreign investment in Riau is Rp. 94,843,552 billion and for PMDN 101,840,664 billion. In the realization of this investment, it is necessary to have a review by the government, because the ratio is very high between PMA and PMDN. With the increasing of investment can affect the increasing of production capacity, it is hoped that it can increase labor productivity to produce output and additional value, thereby increasing economic growth. This increasing in production capacity can be obtained through private investment (private investment) which can be called large-scale domestic investment or domestic investment called foreign investment. Furthermore, another factor affecting poverty is the provincial minimum wage. This policy also affects the poverty level. The determination of the minimum wage aims to ensure that in the long term the minimum wage can at least meet the minimum living needs, so that it is hoped that it can guarantee the workforce to meet the needs of life and their families and at the same time encourage the increasing of work productivity and labor welfare. Based on the Minister of Manpower Regulation Number: Per-01 / Men / 1999, the minimum wage is the lowest monthly wage consisting of the basic wage including fixed allowances.

Table 5

$\underline{\text { Riau Province Minimum Wage 2015-2017 }}$

\begin{tabular}{lccc}
\hline & \multirow{2}{*}{ City } & & Province Minimum Wage/city/Rupiah \\
\cline { 2 - 4 } & $\mathbf{2 0 1 5}$ & $\mathbf{2 0 1 6}$ & $\mathbf{2 0 1 7}$ \\
\hline Kuantan Singingi & 1.980 .000 & 2.207 .700 & 2.389 .835 \\
Indragiri Hulu & 1.950 .000 & 2.174 .473 & 2.440 .845 \\
Indragiri Hilir & 1.940 .000 & 2.163 .658 & 2.342 .160 \\
Pelalawan & 1.925 .000 & 2.176 .480 & 2.356 .040 \\
Siak & 1.982 .000 & 2.209 .930 & 2.392 .249 \\
Kampar & 1.918 .000 & 2.138 .570 & 2.315 .002 \\
Rokan Hulu & 1.925 .000 & 2.146 .375 & 2.323 .451 \\
Bengkalis & 2.225 .000 & 2.480 .875 & 2.685 .547 \\
Rokan Hilir & 1.910 .000 & 2.129 .650 & 2.305 .346 \\
Kepulauan Meranti & 1.940 .000 & 2.163 .100 & 2.341 .556 \\
Pekanbaru & 1.925 .000 & 2.146 .375 & 2.352 .577 \\
Dumai & 2.200 .000 & 2.453 .000 & 2.655 .373 \\
\hline RIAU & $\mathbf{1 . 8 7 8 . 0 0 0}$ & $\mathbf{2 . 0 9 5 . 0 0 0}$ & $\mathbf{2 . 2 6 6 . 7 2 2}$ \\
\hline \multicolumn{1}{c}{ Sounyyyy}
\end{tabular}

Source: Central Bureau of Statistics, Riau Province 
According to Law no. 13/2003, the minimum wage is directed at achieving the need for a decent life by taking into account labor productivity and economic growth. Riau is one of the provinces with a high minimum wage. This is one of the attractions of job seekers from outside the province to enter and join the labor market in Riau Province. The government's policy is to increase the minimum wage in an area and will have an impact on the increasing of average wage for workers in Riau Province. The higher of the increasing minimum wage, the lower of the increasing poverty rate in Riau. The minimum wage rate has increased from year to year, seen in 2015 amounting to Rp. 1,878,000, - and becomes Rp. 2,266,722, - in 2017. The following more detail can be seen the development of UMP in Riau Province in 2015-2017. The condition in Table 5 shows that Riau provincial government took the right policy steps to reduce unemployment which triggered a reduction in the poverty rate of Riau Province. With the level of minimum wage increasing every year, only a part of it can meet the needs of a decent life. This is evidenced by the increasing poverty and high unemployment rates.

1. Does the job opportunities affect poverty in Riau Provincepartially?

2. Does the investment affect poverty in Riau Provincepartially?

3. Does theeffect of minimum wages affect poverty in Riau Provincepartially?

\section{Literature Review}

Poverty is always identified with lack, helplessness, and inability to live properly. The concept of poverty accommodates many aspects, low consumption of food and housing, low quality of health and difficulty in accessing health facilities, not being absorbed into the labor market and political powerlessness (Maggio, 2004, p. 197; Aamir et al., 2010). The economic development and poverty are closely related, and are ways to improve living standards, but sometimes development does not succeed in eliminating poverty. Many factors contribute to this, including the unequal development that has resulted in inequality of opinion which sometimes appears as a result of development (Nielsen, 1994, p. 105). In the neoclassical perspective, inequality is not considered a problem because it cannot be avoided. In the end, modernization, industrialization, and development are believed to be able to reduce inequality itself. The trickledown effect allows everyone to enjoy the increasing of welfare. Globalization in rich countries will be able to provide benefits for countries with low per capita income. However, because the purpose of the development of policies is to break the cycle of poverty have failed, the assumption that poverty exists because of institutional discrimination will emerge. Furthermore, some suggested five characteristics of the poor. The five characteristics of the poor are: 1) Do not have their own production factors, 2) Do not have the possibility to obtain production assets by themselves, 3) The education levels are generally low, 4) Many of them do not have facilities, and 5) Among them they are relatively young and do not have adequate skills or education.

The World Bank (1990) in its report before UN members entitled "Poverty and Human Development 'said that:" The case for human development is not only or even primarily an economic one. Less hunger, fewer child death, and better change of primary education are almost universally accepted as important ends in themselves "(human development is not only prioritized on the economic aspect, but what is more important is to prioritize the universal aspects of education for the self-interest of the poor in order to improve the socioeconomic life). Booth and MeCawley in Moeljarto, (1993, p.103) stated that in many countries there arethe increasing of social welfare level as measured by per capita income, but it can only be enjoyed by a small part of the population. Sharp et al. in Sukmaraga $(2011$, p.147) identified the causes of poverty from an economic perspective. First, on a micro level, poverty arises because of the unequal patterns of resource ownership so that the distribution of income is unequal. Second, the poverty due to differences in the quality of human resources. Third, poverty due to the differences in access to capital.

Human investment aims to improve the intelligences mentioned above. The returns on these investments are still influenced by the personal qualities that are innate and the efforts to improve those qualities. Human investment also requires the measurements to show the efficiency of the investment made. One method that can be used is IRR (Internal Rate of Return). Investment in general is an investment activity by investors. Dornbusch and Edwards (2007) explained that investment is the demand for goods and services to create or increase production capacity or income in the future.

This increasing of of capital goods amount will produce more goods and services in the future, but it is also done because the replacement of old capital goods is already used and the depreciation value is needed. Investment as an expenditure aimed at adding goods or maintaining capital. This capital stock includes machines, factories, and other durable goods used in the production process. The Investments are made because of the expectation of greater profits in the future than today. Investments made by the investors are not to fulfill their own needs, but rather because they seek profit and profit. Therefore, the amount of profit obtained will greatly affect the amount of investment made by investors. There are still other factors such as interest rates, forecasts of the future state of the economy, technological progress, the level of national income, and the profits earned by companies also influence the level of investment. The human factor is changeable in nature. The value of labor which is reflected in wages is greatly influenced by the quality of these human resources. The higher of the workforce quality, the higher of the wages received, and vice versa the low of the labor quality, the low of the wages received. In addition, a qualified workforce will 
be able to increase their work productivity. Human resources contain 2 (two) definitions, there are (1) human resources which contain the definition of work effort, means that human resources reflect the quality of effort given by someone in a certain time to produce goods and services; and (2) human resources related to people who are able to work for providing the service or work business. This employment problem argues that excess labor is an opportunity and not a problem. The excess of workers in one sector will contribute to the growth in output and supply of workers in other sectors. The definition of labor is the population of working age (15-64 years) or the total population in a country that produces goods and services if there is a demand for labor in an activity. The workforce is grouped into 2 (two), there are: (1) labor force; and (2) not the workforce. The work force consists of groups who are working, unemployed and / or who are looking for working. Meanwhile, groups that are not in the workforce consist of those who are still in school and receive income. The number of workers who work is a picture of the conditions of the available employment. According to Law Number 13 of 2003, labor is anyone who is able to do work to produce goods and or services to meet their own needs or labor can also be defined as the working age population who are ready to do work. The determination of the minimum wage policy is as a social safety net, so that wages do not continue to decline as a result of labor market imbalance (disequilibrium labor market). This is also to ensure that the wage levels of workers at lower levels do not fall to very low levels due to the low bargaining position of workers in the labor market. So that workers at this lower level can still live fairly and have their nutritional needs fulfilled, then the determination of the minimum wage takes into account the standard of living of the workers.

The policy for determining the minimum wage as stipulated in Law Number 13 of 2003 is directed at achieving Decent Living Needs in addition to provide guarantees for workers / laborers who receive wages to meet the necessities of life. The program to achieve the minimum wage for Decent Living Needs has shown real improvements. This means that the fulfillment of life's needs will be achieved gradually.

\section{Methods}

The data used in measuring the research variables is secondary data in the form of time series data between 1989-2018 (30 years). The required data is taken from the Central Bureau of Statistics, Central Statistics Agency of Riau Province and Bank Indonesia. The variables of this study consist of independent variables, intermediate variables and dependent variables. The independent variables are Investment t-1 (X1t-1), Investment t-2 (X2t-2, Job Opportunities (X3), and Provincial Minimum Wage (X4). The dependent variable is poverty (Y). This regression analysis is used with the Eviews application, various types of classical assumption tests can be carried out which are the requirements: Normality test, Multicollinearity test, Heteroscedasticity test, and Autocorrelation test, while the framework is as follows:

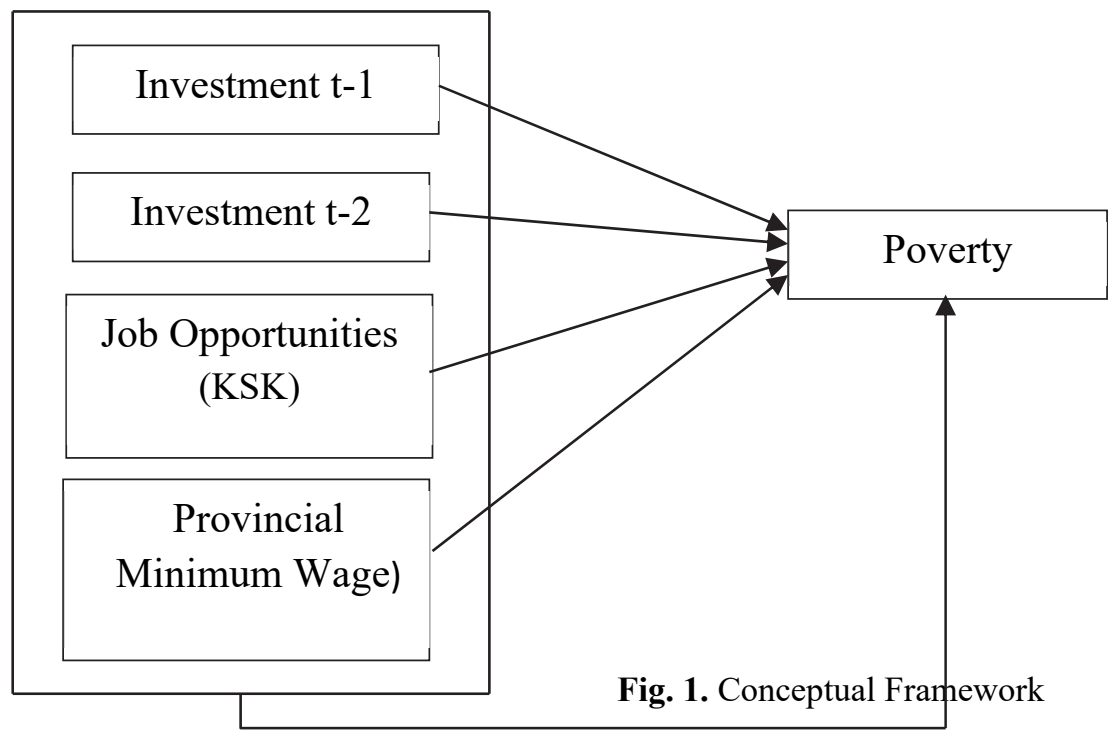

Information

$\mathrm{Xt}-1=$ Investment $\mathrm{t}-1$ (INVt-1)

$\mathrm{Xt}-2=$ Investment $\mathrm{t}-2(\mathrm{INVt}-2)$

$\mathrm{X} 2$ = Job Opportunities (KSK)

$\mathrm{X} 3$ = Provincial Minimum Wage (UMP)

$\mathrm{Y}=$ Poverty $(\mathrm{KMN})$ 
Based on the framework of thought above, the following equation can be formulated:

$Y=f\left(X_{1 t-1}, X_{2 t-2}, X_{3}, X_{4}\right)$

$Y t=\beta_{0}+\beta_{1} X_{t-1}+\beta_{2} X_{t-2}+\beta_{3} X_{3}+\beta_{4} X_{4}+\epsilon_{1}$

$\operatorname{LnYt}=\beta_{0}+\beta_{1} \operatorname{Ln} X_{I t-1}+\beta_{2} \operatorname{Ln} X_{2 t-2}+\beta_{3} \operatorname{Ln} X_{3}+\beta_{4} \operatorname{Ln} X_{4}+\epsilon_{1}$

$L n K M N t=\beta_{0}+\beta_{1} L n I N V_{t-1}+\beta_{2} L n I N V_{t-2}+\beta_{3} \operatorname{LnX} X_{3}+\beta_{4} \operatorname{Ln} X_{4}+\epsilon_{1}$

\section{Results and Discussion}

Based on the results of mathematical equation data processing based on the coefficients and constants obtained in the "Coefficient" output table, simultaneous equation modeling can be structured as follows:

Table 6

The results of Regression

\begin{tabular}{lcccc}
\hline \multicolumn{1}{c}{ Variable } & Coeficiens & Std Error & t-Statistic & Prob \\
\hline C & -11.741 & 35.969 & -0.326 & -0.747 \\
LnINVt-1 & 0.493 & 0.185 & 2.676 & 0.038 \\
LnINVt-2 & 0.745 & 5.548 & 0.134 & 0.894 \\
LnKSK & 0.638 & 0.244 & 2.615 & 0.039 \\
LnUMP & 0.891 & 0.212 & 4.203 & 0.008 \\
\hline \hline R-squared & 0.9540035 & Mean devendent var & & 13.44939 \\
Adjusted R-squared & 0.9409002 & S.D dependent var & & 0.331125 \\
S.E of regression & 0.080497 & Sum squared resid & & 0.136074 \\
Durbint Watson Stat & 1.432638 & J-statistic & 4.820568 \\
Instrument Rank & 12 & Prob (J-statistic) & & 0.436906 \\
F-statistic & 12.664 & & & \\
Prob(F-statistic) & 0.000 & & & \\
\hline Inverted AR Roots & 97 & -97 & & \\
\hline Sol Din
\end{tabular}

Source: Data processing results

$L n K M N t=-11.741+0.493$ LnINVt-1 +0.745 LnINVt-2 +0.638 LnKSK +0.891 LnUMP $+e$

From the above equation, it can be seen that the constant value is $-11,741$. This figure explains, if it is assumed that the total value of the independent variables (lag-1 investment, lag-2 investment, job opportunity, and provincial minimum wage) is equal to zero (none), then the poverty of Riau Province will decrease by 11.741678 units.

The lag-1 investment variable regression coefficient is 0.493 . This figure is positive and gives meaning, if it is assumed that the lag-1 investment increases by 1 unit, while the lag-2 investment variable, employment opportunities, and the provincial minimum wage do not change (constant), then the poverty in Riau Province in the following year will increase by 0.493 units and vice versa.

The lag-2 investment variable regression coefficient is obtained at 0.745 . This figure is positive and gives the meaning, if it is assumed that the lag- 2 investment variable increases by 1 unit while the lag-1 investment variable, employment opportunities and provincial minimum wages do not change (constant), then the poverty in Riau Province in the following year will also increase in 0.745 units and vice versa. The regression coefficient for the employment opportunity variable is 0.638 . This figure is positive and gives the meaning, if it is assumed that the job opportunity variable increases by 1 unit while the lag- 1 investment variable, lag-2 investment, and the provincial minimum wage do not change (constant) then the poverty in Riau Province in the following year will also increase by 0.638 unit and vice versa. Carvantes GD and Dewbre (2010, p.167) conducted a study entitled "Economic Importance of Agriculture for Poverty Reduction" employment opportunities in the agricultural sector and labor productivity in the non-agricultural sector have a significant negative effect on poverty.

The regression coefficient for the provincial minimum wage variable is 0.891 . This figure is positive and gives the meaning, if it is assumed that the provincial minimum wage variable increases in 1 unit while the lag-1 investment variable, lag-2 investment, and job opportunities do not change (constant), then the poverty in Riau Province in the following year will also increase in 0.638 unit and vice versa (Nichols, 2008).

\section{Conclusion}

Based on the results, the conclusions are: 
1. Investment $\mathrm{t}-1$ and investment $\mathrm{t}-2$ have a significant effect both partially and simultaneously on poverty in Riau Province. High investment will stimulate poverty reduction in Riau and vice versa. Because when the investment is increasing, the job opportunities widely opening for people who have been unemployed. They will work and have income.

2. Job opportunities have a significant effect on the GRDP of Riau Province partially. This means that if there is the increasing of job opportunities, it will reduce poverty in Riau Province. This is acceptable because the opening of wide employment opportunities will increase income, then the people's purchasing power will also increase and in the end will make a positive contribution of reduction to the number of poverty in Riau Province.

3. The Provincial Minimum Wage has a significant effect on reducing poverty in Riau Province partially. The increasing of Provincial Minimum Wage will encourage in reducing poverty and vice versa. Because with an adequate Provincial Minimum Wage, it will encourage the increasing of consumption by the community which will reduce poverty.

\section{References}

Achsani, N. A., Fauzi, A. J. F. A., \& Abdullah, P. (2010). The relationship between inflation and real exchange rate: comparative study between Asean+3, the EU and North America. European Journal of Economics, Finance and Administrative Sciences, 18, 1450-2275.

Aamir, M., Karamat, M., \& Rehan, M. F. dkk. 2011. Inflation in Pakistan: Antecendents and Consequences. International Research Journal of Finance and Economics.

Bank Dunia. (2015). Pengentasan Kemiskinan di Indonesia. Diakses pada 20 Juni 2015 , dari http://www.worldbank.org/in/country/indonesia/brief/reducing- extreme-poverty-in-indonesia.

Bank Dunia (1990). Indonesia: Poverty Assessment and Strategy Report. Report, No. 8034-IND, Country Department III East Asia and Pacific Region. Washington

Bank Indonesia (2018). Laporan Inflasi Indonesia, Pustaka Bank Indonesia, Jakarta.

Bouoiyour, J., \& Miftah, A. (2014). The effects of remittances on poverty and inequality: Evidence from rural southern Morocco. Collier, P., \& Dollar, D. (2002). Aid allocation and poverty reduction. European Economic Review, 46(8), $1475-1500$.

Dornbusch, R., \& Edwards, S. (Eds.). (2007). The macroeconomics of populism in Latin America. University of Chicago Press. Frank, R. H., \& Bernanke, B. S. (2007). Principles of Microeconomics, $3^{\text {rd }}$ ed., New York: McGraw-Hill/Irwin.

Hartomo, \& Aziz. (1997). Ilmu Sosial Dasar. Jakarta : Bumi Aksara

Jalilian, H., \& Kirkpatrick, C. (2002). Financial development and poverty reduction in developing countries. International Journal of Finance \& Economics, 7(2), 97-108.

Kaplale, R. (2012). Factor inluencing the level of poverty in Ambon City. Agribisnis Faperta Unpatti Ambon.

Kuncoro, M. (1997). Ekonomi Pembangunan, Penerbit Salemba Empat, Jakarta.

Moeljarto, (1993), Politik Pembanguan Sebuah Analisis Konsep, Arah dan Strategi, PT. Tiara Wacana: Yogyakarta

Nichols, A. (2006). Understanding recent changes in child poverty. Washington, DC: Urban Institute.

Sukmaraga, P. (2011). Analisis Pengaruh Indeks Pembangunan Manusia, PDRB Per Kapita, dan jumlah penggangguran Terhadap Jumlah Penduduk Miskin Di Provinsi Jawa Tengah, Universitas Diponegoro.

Wongdesmiwati (2009). Pertumbuhan Ekonomi Dan Pengentasan Kemiskinan Di Indonesia: Analisis Ekonometrika : Jurnal.

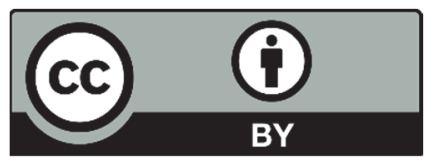

(C) 2021 by the authors; licensee Growing Science, Canada. This is an open access article distributed under the terms and conditions of the Creative Commons Attribution (CC-BY) license (http://creativecommons.org/licenses/by/4.0/). 